This is an electronic reprint of the original article. This reprint may differ from the original in pagination and typographic detail.

Author(s): Kaukua, Jari

Title: $\quad$ A Closed Book: Opacity of the Human Self in Mullā Șadrā

Year: $\quad 2014$

Version:

Please cite the original version:

Kaukua, J. (2014). A Closed Book: Opacity of the Human Self in Mullā Șadrā. Vivarium, 52(3-4), 241-260. https://doi.org/10.1163/15685349-12341273

All material supplied via JYX is protected by copyright and other intellectual property rights, and duplication or sale of all or part of any of the repository collections is not permitted, except that material may be duplicated by you for your research use or educational purposes in electronic or print form. You must obtain permission for any other use. Electronic or print copies may not be offered, whether for sale or otherwise to anyone who is not an authorised user. 


\title{
A Closed Book: Opacity of the Human Self in Mullā Șadrā
}

Jari Kaukua (University of Jyväskylä, Academy of Finland)

\begin{abstract}
Mullā Șadrā Shīrāzī (d. 1636) subscribes at large to the Avicennian view according to which the human subject is always and fully aware of herself. At the same time, his eschatology hinges on the Qur'ānic motive of the soul as a closed book that is first opened on the Final Day, that is, on the idea that each soul's share in the afterlife should be understood as the full revelation of the soul's true nature to itself. The two ideas thus have seemingly contradictory entailments: the soul is fully aware of and transparent to itself, but at the same time it has aspects that can remain opaque to it, at least in this life. The task of this paper is to investigate whether Șadrā can coherently hold on to the two ideas, and what kind of revisions this requires him to make to the received concepts of self and self-awareness.
\end{abstract}

Keywords: self-awareness, psychology, eschatology

The human mind's opacity to itself is often considered as an idea of mature modernity. To borrow Paul Ricoeur's catchphrase, it was especially the "three masters of suspicion" - Marx, Nietzsche and Freud - who showed that we are not quite as transparent to ourselves as Descartes had suggested and as we'd perhaps still like to think. In their thought selfawareness is no longer an indubitable foundation or paradigm for knowledge; it may hide more than it reveals, and it may be conditioned by economical, biological and libidinal forces, or structured by the mind's cognitive apparatus, language, social interaction and other factors that render any such thing as the self behind the appearances all but inaccessible to us. 
Becoming aware of one's true self has since been a matter of interpretative striving, not of straightforward introspection. ${ }^{1}$

Arabic philosophy is not short of proponents of the self's transparency. Instigating the discussion of human self-awareness in Arabic philosophy, ${ }^{2}$ Avicenna emphasized its immediacy and claimed as a consequence that it is undeniable and complete at every moment of human existence; although we may need to be alerted to the fact that we are aware of ourselves, this awareness does not depend on such second-order alertness nor is it in any way increased by it. The development of this insight into a novel concept of knowledge as "presence" (huḍūr) by Shihāb al-Dīn Suhrawardī (d. 1191) shows that the underlying conviction was not unlike that of an Augustine or a Descartes: if anything is fully present to me, it is myself, and if there's anything I should be said to know in the paradigmatic sense of the word, it is my self. Although the analysis and the alleged demonstrative power of selfawareness were subject to some debate, ${ }^{3}$ the stance of Avicenna and Suhrawardi became the received view in post-classical Arabic philosophy. It is thus surprising to find Mullā Șadrā (d. 1636), the great synthesizer of the various strands of Muslim learning, connect it to the much less optimistic strand of thought emphasizing God's cognitive superiority even in our most intimate matters. This is especially pronounced in Șadrā's insistence on the Qur'ānic

\footnotetext{
${ }^{1}$ P. Ricoeur, Freud and Philosophy: An Essay on Interpretation (New Haven and London, 1970), 32-36.

2 Although it was Avicenna's way of thematizing self-awareness that proved formative for most of the subsequent discussion in both philosophy and theology, he was not the first Arabic author to pay attention to human self-cognition. Already the early Bașran $\mathrm{Mu}$ 'tazilite Mu'ammar ibn 'Abbād al-Sulamī (d. 830) put forth an argument closely resembling Avicenna's famous flying man (see M. Sebti, Avicenne: L'âme humaine [Paris, 2000], 119), and evidence based on first-personal experience plays an important role in the philosophical anthropology of the mature Mu'tazilism of 'Abd al-Jabbār (d. 1025) and his student Ibn Mattawayh (see. S. Vasalou, 'Subject and Body in Bașran Mu'tazilism, or: Mu'tazilite kalām and the Fear of Triviality', Arabic Sciences and Philosophy 17 [2007], 267-298: 276-283).

${ }^{3}$ Consider, for instance, the records in Avicenna's Nachlass: Al-Mubāhathāt. Abū 'Alī Husayn ibn 'Abd al-Lāh ibn Sìnā, ed. M. Bīdārfar (Qom, 1992) (henceforth Mubāhathāt), III.47-74, 55-62; and J. R. Michot, 'La Réponse d'Avicenne à Bahmanyār et al-Kirmānī: Présentation, traduction critique et lexique arabe-français de la Mubāhatha III', Le Muséon 110 (1997), 143-221. In the twelfth century CE, Abū al-Barakāt al-Baghdādī and Fakhr al-Dīn al-Rāzī introduced a number of qualifications and critical remarks to Avicenna's discussion of selfawareness (see S. Pines, 'La Conception de la conscience de soi chez Avicenne et chez Abu'l-Barakat alBaghdadi', Archives d'histoire doctrinale et littéraire du moyen āge 29 [1954], 21-98; M. E. Marmura, 'Fakhr al-Dīn al-Rāzī’s Critique of an Avicennian Tanbīh', in Historia Philosophiae Medii Aevi: Studien zur Geschichte der Philosophie des Mittelalters, eds. B. Mojsisch \& O. Pluta [Amsterdam, 1991], 627-641; and J. Janssens, 'Fakhr al-Dīn al-Rāzī on the Soul: A Critical Approach to Ibn Sīnā', The Muslim World 102 [2012], 562-579).
} 
metaphor of the human soul as a book that is first opened on the Final Day for the soul itself to read and fathom what it really was. ${ }^{4}$ If God knows me better than I myself do, I must be opaque to myself in one respect or another.

In the present paper I attempt to explain Șadrā's departure from the philosophical mainstream as a consequence of his systematic commitments. Although he largely subscribes to his predecessors' discussion of human self-awareness, his theories of the primacy of existence, unity of subject and object of all cognition, and substantial motion, force him to revise the received concept of self and to qualify its transparency.

By Șadrā's time, the Avicennian discussion of the self and self-awareness was a firm part of the received tradition. ${ }^{5}$ Much in this discussion hinges on the observation that all human experience is first-personally given, or entails a first-personal subject - the self - as one of its necessary constituents. Correspondingly, talk of self-awareness (most often, but not always, designated by the technical term shu 'ür bi al-dhāt) only refers to the fact that we are aware of all our contents of experience in the first person. Each of us has this first-personality hardwired, although explicit attention to it is a rare phenomenon and may require quite extraordinary manoeuvres of thought, such as the well-known thought experiment of the

\footnotetext{
${ }^{4}$ Cf. Q 7:187, 17:13-14, 18:49, 50:22, 81:10.

${ }^{5}$ For the Avicennian roots of the discussion, see Sebti, Avicenne: L'âme humaine, 103-124; D. Black, 'Avicenna on Self-Awareness and Knowing that One Knows', in The Unity of Science in the Arabic Tradition: Science, Logic, Epistemology and their Interactions, eds. S. Rahman, T. Street, and H. Tahiri (n.p., 2008), 63-87; D. Black, 'Avicenna on Individuation, Self-Awareness, and God's Knowledge of Particulars', in The JudeoChristian-Islamic Heritage: Philosophical and Theological Perspectives, eds. R. Taylor and I. Omar (Milwaukee, 2012), 255-281; and J. Kaukua, Self-Awareness in Islamic Philosophy: Avicenna and Beyond (Cambridge, forthcoming), chs. 2-4. Some phases of the subsequent development are covered in R. D. Marcotte, 'Suhrawardī's Apperception of the Self in Light of Avicenna', Transcendent Philosophy 5 (2004), 1-22; L. Muehlethaler, 'Ibn Kammūna (d. 683/1284) on the Argument of the Flying Man in Avicenna's Ishārāt and alSuhrawardī's Talwīhāt', in Avicenna and his Legacy: A Golden Age of Science and Philosophy, ed. Y. T. Langermann (Turnhout, 2009), 179-203; J. Kaukua, 'I in the Light of God: Selfhood and Self-Awareness in Suhrawardī's Hikmat al-ishrāq', in In the Age of Averroes: Arabic Philosophy in the Sixth/Twelfth Century, ed. P. Adamson (London and Turin, 2011), 141-157; J. Kaukua, 'Suhrawardī's Knowledge as Presence in Context', Studia orientalia 114 (2013), 309-324; and Kaukua, Self-Awareness in Islamic Philosophy, chs. 5-8.
} 
flying man. ${ }^{6}$ Building on this constancy of self-awareness, Avicenna claimed that it is constitutive, essential, and innate to each of us. ${ }^{7}$ The outcome is that, as the essential core of each human being, the self will always be fully given, transparent, or as the later technical term had it, present (hâadir) to itself. We can of course err about the nature of our selves, for instance by identifying them with our bodies, but the mistakes only amount to unwarranted identifications between various accidental features and the self, the initial transparency of which is thereby neither contested nor obscured.

An array of passages can be brought forth as evidence of Șadrā's debt to Avicenna in this regard. We can find Sadrian versions of the flying man, ${ }^{8}$ the argument from the unity of experience to a single self behind all its constituents, ${ }^{9}$ and the argument against reflectionbased models of self-awareness, ${ }^{10}$ only to mention some of the most prominent cases. The following passage sums up the concept that Șadrā thereby subscribes to:

We apprehend ourselves (dhawātanā) through our very form through which we are we, not through a form additional to it. Thus, every human being apprehends himself (dhätahu) in a manner which prevents sharing. $[\ldots][\mathrm{W}] \mathrm{e}$ refer to every universal concept and mental form - even if it were something subsisting through our self (dhätinā $)$ - by 'it' whereas our self (dhātināa we refer to by 'I', and our knowledge of our self is identical to

\footnotetext{
${ }^{6}$ For the flying man, cf. M. Marmura, 'Avicenna's "Flying Man” in Context', The Monist 69 (1986), 383-395; and Muehlethaler, 'Ibn Kammūna (d. 683/1284) on the Argument of the Flying Man'.

${ }^{7}$ Ibn Sinnā: al-Ta'līqāt, ed. 'A. Badawī (Cairo, 1973), 160-161.

${ }^{8}$ Sadr ad-Din Muhammed Shirazi Mulla Sadra (979-1050 A. H.): Al-Hikmat al-muta'aliyah fi'l-Asfar al-arba'a al-aqliyyah (Transcendent Philosophy in Four Intellectual Journeys), eds. S. M. Khamene'i et al. (Tehran, 2001-2005), IV.2.2, VIII.47 (this edition will henceforth be referred to as Asfār, followed by numbers for section and subsections [e.g. IV.2.2], and volume and page [e.g. VIII.47]); cf. Al-Shawāhid al-rubūbìyah (Divine Witnesses) by Sadr al-dīn Shīrāzì (Mullā Sadrā) with the Complete Glosses of Hājjī Mullā Hādī Sabziwārī, ed. S. J. Āshtiyān̄̄ (Mashhad, 1967), II.2.2, 212 (this edition will henceforth be referred to as Shawāhid, followed by numbers for section and subsection, and page).

${ }^{9}$ Asfār IV.2.5, VIII.71; IV.8.5, IX.72-73; IV.5.4, VIII.265-267. For the Avicennian precedent, see Kaukua, SelfAwareness in Islamic Philosophy, ch. 4.1; and H. Lagerlund, 'The Unity of the Soul and Contrary Appetites in Medieval Philosophy', in The Achilles of Rationalist Philosophy, eds. T. M. Lennon and R. J. Stainton (n.p., 2008), 75-91.

${ }^{10}$ Asfār I.10.2.4, III.505; IV.2.2, VIII.46-47; and IV.6.1, VIII.320-326. For the Avicennian precedent, see Ibn Sinna: Le Livre des theorems et des avertissements, ed. J. Forget (Leiden, 1892), 120 (this edition will henceforth be referred to as Ishärāt, followed by page number).
} 
the existence of our self and our individual being ('ilmunā bi dhātinā 'aynu wujūdi dhātinā wa huwiyyatinā alshakhșiyya). ${ }^{11}$

There are two points to note here. First, Șadrā identifies self-awareness with the existence of the individual human being. ${ }^{12}$ As a corollary, self-awareness is not a piece of acquired knowledge but a state that prevails throughout our existence as immaterial substances. Secondly, self-awareness is exclusive to each self. This is because one can be aware of a self only by being that self, a fact which is borne out by the unique deictic properties of the firstperson indexical, contrasted here with the properties of the third-personal 'it'. ${ }^{13}$

The fact that self-awareness is not acquired but a constant feature of the self already hints at the idea that the self is transparent to itself. By the same token, if being capable of first-personal indexical reference is all that constitutes the self, there is little that could conceivably remain obscure to such an I of itself. It is therefore surprising to find that in the eschatological section of the very same work, Sadrā insists on the Qur'ānic topos of the opening of the soul's book on the final day - an idea which seems to be in polar opposition to the self's transparency. If anything, he increases the tension by describing (in reference to Q 81:10) the human being's resurrection as "the time [...] for his sight to fall upon the face of his self and turn to the page of his interiority and the tablet of his conscience (damīrihi)". ${ }^{14}$ The clear implication is that in resurrection the person acquires a new awareness of himself, when for the first time he perceives the true nature of his self in a clear and veridical, if often

\footnotetext{
${ }^{11}$ Asfär III.1.3.1, VI.149.

${ }^{12}$ This is an entirely Avicennian move, but unlike Avicenna according to whom the human individual is an immaterial substance from the very beginning, Sadrā holds the identification to concern only a confined period in the existence of a human individual, namely the period subsequent to having developed from an enmattered form into a mentally existing immaterial substance. For a more extended discussion of this difference, see Kaukua, Self-Awareness in Islamic Philosophy, ch. 3.2.

${ }^{13}$ The contrast is borrowed from Suhrawardī; see Sohrawardī: Al-Talwīhāt al-Lawhiyyah va al-Aršiyyah, ed. N. Habībī (Tehran, 2009), II.4.3, 156; and Suhrawardī: The Philosophy of Illumination / Hikmat al-ishrāq, eds. J. Walbridge \& H. Ziai (Provo, 1999), II.1.5.115, 80 (= Euvres philosophiques et mystiques (Shihäbuddīn Yahyā Suhrawardī), ed. H. Corbin [Tehran, 1952], II.111).

${ }^{14}$ Asfār IV.11.20, IX.408. For an extended discussion of the motive, see C. Jambet, Mort et resurrection en Islam: L'au-delà selon Mullā Sadrā (Paris, 2008), 150-203.
} 
unflattering light. What he then sees but earlier failed to perceive is clarified in another passage as "consequences of his deeds and thoughts" and "traces of his movements and acts". ${ }^{15}$ Thus, the human soul or self bears in itself the traces of its morally blame- or praiseworthy acts and thoughts precisely without being fully aware of them. Thus, when it comes to his eschatology, Șadrā’s self suddenly seems decidedly less transparent.

This raises a number of questions. Is Sadrā aware of the potential incoherence? If he is, does he suggest a solution? On the other hand, why does he insist on the Qur'ānic topos? ${ }^{16}$ Is this merely out of piety, or does it signal systematic reasons that remain for the reader to explicate? Admittedly, Șadrā could have been more explicit, but in the following I would like to present and consider some evidence for the view that either he was aware of the incoherence and proposed a solution, or perhaps more likely, was not quite awakened to the looming dilemma because of systematic commitments which had already led him to covertly revise the received concept of self-awareness, and in the light of which the dilemma simply does not emerge. These commitments are (1) the thesis of the primacy of existence (as opposed to quiddity), (2) the unity theory of cognition, and (3) the thesis of motion in the category of substance. Once we understand how the concept of self-awareness is revised in the framework of these ideas, we can trace a way towards a reconciliation of the two statements that now seem incompatible. ${ }^{17}$

\footnotetext{
${ }^{15}$ Asfär IV.11.20, IX.411.

${ }^{16}$ The Asfār is by no means unique in its emphasis of the idea, which has an equally prominent place in less technical works, aimed for a larger public, such as al-Mazāhir al-ilāhiyya (Sadr ad-Dīn Muhammad Shīrāzī Mulla Sadra (979-1050 A.H.): al-Mazāhir al-ilāhiyyah fì Asrār al-Ulum al-Kamāliyyah. Book of Divine Manifestation Concerning the Secrets of the Sciences that Lead to Perfection, ed. S. M. Khāmene'i [Tehran, 1999], II.1, 90-91; II.4, 109-111; II.8, 126, 131-132, 134), Iksīr al-'ārifìn (Mullā Șadrāa: The Elixir of the Gnostics / Iksīr al-'ārifin, ed. W. C. Chittick [Provo, 2003], I.5, 9, 12-13; II.5, 22; II.7-8, 25-27; IV.3, 67-68) and al-Hikma al-'arshiyya (J. Morris, The Wisdom of the Throne: An Introduction to the Philosophy of Mulla Sadra [Princeton, 1981], II.3.7, 197-199).

${ }^{17}$ Since none of these ideas is a matter of particular scholarly controversy, I will treat them very schematically. Our main task is to understand what consequences they have for Șadrā's concept of self and self-awareness.
} 
(1) The term 'primacy of existence' (așāla al-wujūd) captures the peculiarly Șadrian stand in the debate about which of the two Avicennian principles, quiddity or existence, is foundational for the other. ${ }^{18}$ In brief, Șadrā holds that the reality of each individual existent is based on its existence, not on an essence having existence. The temporal variation of its attributes notwithstanding, the creature is one, not because it has an unchanging essence, but because its existence is a single continuity. But existence comes in degrees; in concrete acts of existence, there are always certain deficiencies or privations that distinguish them from the pure and perfect existence that is God's alone. Our intellects can grasp these deficiencies by abstracting them from the unity of the original act of existence, thereby translating them to essential and accidental quidditative features, but in reality, the act and its degree are inseparable. ${ }^{19}$ But intellectual abstraction not only makes a manifold composite out of what is absolutely one, it does this by means of universal concepts which can by definition be true of more than one particular act of existence. This is possible only by neglecting certain aspects of the thing under consideration. It may be perfectly legitimate to conceive a given individual (say, a horse) as a horse of particular color, height, gait, capacities, and breed - as long as one bears in mind that this involves subsuming it under a certain bundle of universals. But what is more, Șadrā claims that I can grasp the horse thereby conceived as being identical to the colt I encountered five years earlier only by abstracting from some of the features in the two respective acts of existence - a clear sign of cognition by means of universal concepts. This is not to say that the identification of the horse with the colt is unwarranted; the point is that the basis of the identity, that is, the continuity of the creature's existence, will elude my narrow intellectual grasp.

\footnotetext{
${ }^{18}$ For an epitome of the distinction and its reception, see R. Wisnovsky, 'Avicenna and the Avicennian Tradition', in The Cambridge Companion to Arabic Philosophy, eds. P. Adamson and R. C. Taylor (Cambridge 2005), 92-136: 105-113.

${ }^{19}$ The best study of the primacy of existence is C. Bonmariage, Le Réel et les réalités: Mullā Sadrā Shīrāzī et la structure de la réalité (Paris, 2007); for a concise account, see especially 45-46, and 66-69.
} 
(2) In a conscious departure from Avicenna's express denial, Șadrā subscribes to the view according to which knowledge is best conceived as a unity (ittihâad) between its subject and object. ${ }^{20}$ All cognition should be understood as an act of mental existence, which can be divided into two interdependent counterparts, one that knows and one that is known, only in second-order analysis. For instance, an intelligible exists in act only by being actually understood. This, however, requires that it be given to an intellectual subject, which in turn can only exist as an actual intellect by understanding the intelligible. Were it not for this single act of intellection, both constituents would be merely potential. ${ }^{21}$ But Șadrā goes further, for having argued for unity in the case of intellection, he asserts it broadly of all types of cognition, including sense perception. ${ }^{22}$ Again, he emphasizes that the unity only prevails in mental existence, that is, in the experiential realm of perception, imagination and intellection. Thus, like any act of existence, an experience should be primarily understood as an indivisible whole, not a composite of a subject and various qualitative features. The subject cannot be really distinguished from its object, because in order to be an actual subject, it must be determined by an actual object. As a corollary of this broad concept of unity, the development from sense perception to imagination and intellection concerns both the subject and the object; the human soul can become an actual intellect only through a corresponding transformation in its object. ${ }^{23}$

(3) Substantial motion (haraka jawhariyya) is an idea of Șadrā's invention according to which motion takes place not only in the categories of quality, quantity, place and position,

\footnotetext{
${ }^{20}$ Avicenna rejects the theory in, for instance, Avicenna's De anima (Arabic Text): Being the Psychological Part of Kitāb al-Shifā' (London, 1959), V.6, 239-240. Avicenna's rejection notwithstanding, the theory derives from Aristotle's idea of the shared actuality of the subject and object of perception and intellection (see, for instance, De an. III.2, 426a2-26; and III.7, 431a1-7). Some of the subsequent stages of the theory are reviewed in I. Kalin, Knowledge in Later Islamic Philosophy: Mullā Șadrā on Existence, Intellect, and Intuition (New York, 2010), 185.

${ }^{21}$ Asfār I.1.10.1.7, III.340-341; and Sadr ad-Din Muhammed Shirazi Mulla Sadra (979-1050 A.H.): Ittihad-i Agil wa Magul, ed. B. Alizadeh (Tehran, 2008) (henceforth Ittihād), I.2, 22-25. For an extended study of Șadrā's theory of knowledge, see Kalin, Knowledge in Later Islamic Philosophy, 86-180.

${ }^{22}$ Asfär I.1.10.1.7, III.342; Ittihăd I.2, 22-25. Here again he follows the Aristotelian principle (see De an. III.2, 426a2-26).

${ }^{23}$ Ittihạd I.3, 27-30.
} 
but also, indeed primarily, in the category of substance. ${ }^{24}$ Sadrā thus stands in polar opposition to the Peripatetic paradigm according to which stability in the category of substance is a necessary condition for apprehending any kind of motion that can only be perceived as a variation of an unchanging substantial essence. ${ }^{25}$ Yet despite this departure from the tradition, Sadrā's immediate aim is to make sense of the teleology underlying all natural processes, or the fact that all existents strive by their very nature to exist well, each pursuing the perfection proper to it. These teleological processes were traditionally conceived as evolution within the set of the concomitant accidents of substances with the substances themselves remaining static. Sadrā counters this by stating that unless the teleology is merely fortuitous, it must concern the very essence of the beings under development; it must be the substance itself that develops and thereby comes to exist more perfectly. Șadrā also conceives of this development as a gradual increase in the being's individuality as it acquires new degrees of perfection which, by being founded upon the earlier, encompass them within themselves. $^{26}$

To illustrate the process of substantial development, let us briefly consider Saadrā's favorite example of the human being. We first come to the world as material forms of the embryos in our mothers' wombs. Once our cognitive organs have reached a sufficient stage of development, we begin to actually perceive, which entails an ascent to a new level of mental existence. Our newly acquired actuality as immaterial substances is, however, but an initiation into a considerably more grandiose development within the sphere of mental existence. We first ascend from perception to imagination, which amounts to an increased independence

\footnotetext{
${ }^{24}$ The theory of substantial change is introduced at length in Asfâr I.1.7.18-32, III.71-137. Despite the prominence of the theory in Șadrā, we lack a definitive study. The best attempt remains F. Rahman, The Philosophy of Mullā Sadrā (Șadr al-Dīn al-Shirāazi) (Albany, 1975), 94-108. M. Dehbashi, Transubstantial Motion and the Natural World with a Translation of Volume III, Stage 7, Chapters 18-32 of the Asfar of Mulla Sadra (London, 2010) is a problematic translation of the key chapters.

${ }^{25}$ For the Peripatetic view, see Ar. Phys. V.1, 225a20-29; V.2, 225b10-16; and Avicenna: The Physics of The Healing / Al-Shifä': Al-Samā' al-țabì'iyy, ed. J. McGinnis (Provo, 2009), II.3.7-20, 141-150 (and cf. II.3.2, 136137). Substances do of course perish and come to be (and in this sense they are subject to change [metabolē] though not motion [kinēsis]; see Ar. Phys. V.1, 225a1-19) but since this takes place in a durationless instant, it does not qualify as motion.

${ }^{26}$ See Rahman, The Philosophy of Mulla Sadrā, 100-102.
} 
from the material constraints of the sublunary world, and in turn contains the potency for intellection, the final ascent in the substantial motion of human being. In this process, no substantial core of our being will remain immutable through the successive steps from lower to higher levels of existence. ${ }^{27}$ The motion concerns the human substance, our very selves, and distinct stages in the process cannot be unqualifiedly identified with each other. Like in our earlier example of the horse, the infant John and the adult John are two different entities.

The theory of substantial motion thus leads back to the primacy of existence. The two stages in John's development can belong to one individual only because they belong to one and the same process, a single continuity of existence. ${ }^{28}$ Although this continuity is metaphysically primitive and thus unanalyzable by means of more foundational concepts, such as a stable substantial essence, it is directed by an internal teleological principle. ${ }^{29}$ This principle is the Sadrian equivalent of the Peripatetic concept of substance in the sense that the identity of an individual existent is founded upon it, but unlike the Peripatetic substance, it can only exist as the infinitely rich continuity of motion and can therefore not be abstracted from any particular phase in that continuity. ${ }^{30}$

Avicenna's concept of self-awareness is founded upon an intuition about a self (the I) that is really separable from its accidental attributes. This feature is hinted at by the flying man,

\footnotetext{
${ }^{27}$ Asfār I.1.7.19, III.76.

${ }^{28}$ Asfär I.1.7.19, III.74-76; I.1.7.22, III.83; I.1.7.24, III.95; and cf. IV.11.11, IX.330. Șadrā's concept of identity bears an interesting resemblance to four-dimensionalist or perdurance theories of identity in analytic metaphysics (as Rahman, The Philosophy of Mullā Șadrā, 109, citing 'Allāma Sayyed Muhammad Husayn Țabāṭabā'̄̄, also suggests). For a concise account of these theories, see A. Gallois, 'Identity Over Time', in The Stanford Encyclopedia of Philosophy (Summer 2012 Edition), ed. E. N. Zalta, URL = $<$ http://plato.stanford.edu/archives/sum2012/entries/identity-time/>.

${ }^{29}$ See Sadr ad-Din Muhammed Shirazi Mulla Sadra (979-1050 A. H.): Mafatih al-Qayb, ed. N. Habibi (Tehran 2007) (henceforth Mafātīh), XVII.3, 938-939.

${ }^{30}$ Sadrā does grant that these principles have a certain stability, for he says that prior to their existence, they are eternally fixed in God's mind (Asfär I.1.7.25, III.106-108; cf. IV.11.1, IX.265). This suggests the influence of Ibn 'Arabī and his concept of fixed essence ('ayn thābit), but the details of the relation cannot be addressed within the present confines.
} 
which hinges precisely on the supposition that in a special situation we may be aware of nothing but ourselves, but it is especially evident in the arguments based on intuitions concerning our personal identity, which Avicenna applies to distinguish the self from accidental features that are due to our relations to our bodies. Since all these features are subject to change and cessation, the self that remains intact throughout their variation must be really separate from them. ${ }^{31}$

True to his theory of substantial motion, Șadrā denies the stability of any substantial core in the self. As temporal entities, human selves are subject to thoroughgoing development; at an early stage of mental existence, the percipient and imaginative human being is a merely potential intellect, but then "its self (dhâtuhā) evolves and is transferred in this substantial transformation from an imaginative faculty to an intellectual faculty". ${ }^{32}$ The same point is made more explicitly - in an explicit departure from Avicenna, but like him relying on the interlocutor's intuition - in a late summa:

The soul has an aspect of permanence (istimrār) and an aspect of renewal (tajaddud) due to its connection to two extremes: the intellect and hyle. Whoever returns to his intuition (wijdānihi) will find out that this present being (al-huwiyya) is different from the past and the future being, not merely due to the difference of accidents but due to the difference of the phases of a single self (ațārin li dhātin wähidatin). ${ }^{33}$

A related passage from the Asfār goes even further by suggesting that our substantial change involves a multitude of I's:

\footnotetext{
${ }^{31}$ Cf. Mubāḥathāt VI.402-403, 146-147; and Al-Ạ̣hawiyya fì al-ma'ād li Ibn Sīnā, ed. Ḥ. 'Āṣ̂̄ (Beirut, 1987), IV.127-128. This of course does not mean that the self cannot have any attributes, but only that its existence is independent of any of them.

${ }^{32}$ Asfār IV.9.5, IX.151.

${ }^{33}$ Shawāhid II.2.8, 230; cf. Mafätīh XV.4.7, 894, which renders the point almost word for word, only replacing 'phases' with 'states' (shu'ünāt).
} 
Pythagoras is reported to have said: “A spiritual essence (dhātan) shone knowledge (al-ma 'ärif) upon me, and I asked: who are you? It said: I am your complete nature". [What is reported] ${ }^{34}$ supports this thesis. Oh my beloved, if you were allowed to ascend to levels of your being, you would see a number of beings (huwiyyat) differing from each other in existence, each of them a completeness of your being which lacks nothing of you, and each one of them referred to as 'I'. This is like in the famous proverb: "You are I, so who am I (anā anta fa man anā)?"35

The passage is allusive, but it can be reconstructed to make a determinate point. Having explicitly linked the oracular statement to the theory of substantial motion, Sadrā suggests that the plurality of beings (huwiyyatt) entailed by the theory concerns the very core of Avicennian self-awareness, the I. Each phase in my existence is a different I, yet at the same time I am completely present to myself at each phase. This raises a puzzle which Șadrā expresses by means of the Arabic proverb, the gist of which is lost in translation. Since the Arabic does not require a copula, the phrase is genuinely ambiguous, and can also be rendered as 'You are (an) I, so who is (the) I?' This reading signals that Sadrā is fully aware of the questions concerning identity that a concept of self in development raises. Can I in any reasonable sense identify with the former or future phases in my development? In what sense is the development mine to begin with? Which, if any, of the consequent I-phases can legitimately claim to be the proper subject of the development?

I will return to these worries in short, but let us first have a look at how Sadrā describes the motion taking place in the self. This brings in the question of the consequences that the thesis of cognitive unity had for his concept of self. If all acts of cognition, from the lowest grade of tactile perception to the highest degree of intellection, are unities of subject and object which, though distinguishable in analysis, are in reality interdependent for their existence, then the self, as the subject of cognition, is by necessity determined by the contents

\footnotetext{
${ }^{34}$ This is a reference to the theory of substantial motion.

${ }^{35}$ Asfär IV.7.3, VIII.422-423.
} 
of experience it happens to have. Or to phrase the point more precisely, instead of a distinct entity the self is an inseparable aspect of a single experiential whole. Șadrā endorsed this departure from his predecessor in full knowledge, for in the course of an extended argument against transmigration he states it as intuitively obvious that the human self is aware of its capacities of perception and voluntary movement, that is, capacities commonly thought to involve the body, even when it is not engaged in the corresponding activities. This claim is followed by a series of formulations that bring home the point that the self is one with its action and its objects:

The psychic human has sensations of things by himself and judges them by himself, not by means of a natural instrument that he would need in his apprehension and act [...]. Thus, his self by itself (dhātuhu bi dhātihi) is sight for apprehending what is visible and hearing for apprehending what is audible; and in like manner for every species of what is sensible, and so he in himself ( $f \grave{i}$ dhätihi) is hearing, sight, smell, taste, and touch for himself (li dhātihi). Furthermore, he judges by himself about estimative premises and others, not by means of any additional forms of the premises, and he is desire for himself of what is desirable and anger for himself of what is repulsive, with no additional desire or anger. ${ }^{36}$

As the context makes clear, Șadrā applies the crypto-Plotinian term 'psychic human' (al-insān al-nafsiyy) ${ }^{37}$ to refer to a human being who has ascended to the level of mental existence and thereby become an act of self-aware existence. Thus, the passage identifies a mentally existing human being "in himself and for himself" with the acts of sense-perception as well as of the higher cognitive acts of the Avicennian internal senses, represented here by estimation, ${ }^{38}$ of the motive faculties, and ultimately those of the intellect. When it brings the

\footnotetext{
${ }^{36}$ Asfār IV.8.7, IX.92.

37 The term is introduced in a quote from the Theology of Aristotle, cf. Plotinus apud Arabes: Theologia Aristotelis et fragmenta quae supersunt, ed. 'A. Badawī (Cairo, 1955), X, 146.

${ }^{38}$ In his cognitive psychology, Sadrā subscribes to the Avicennian classification of the internal senses to the common sense, imagery, estimation, memory, and imagination (see Asfär IV.2.4, VIII.59-61; and IV.5.1-3, VIII.243-260). For concise accounts of Avicenna's theory, see D. Black, 'Imagination and Estimation: Arabic
} 
corresponding objects to be in its cognitive acts, the mentally existing self is determined by them to be the very individual it is, in each case a "this I aware of this $x$ ", making the self fundamentally intertwined with the contents of its experience. Self-awareness is thus always simultaneously awareness of the faculties that the self always already finds itself operating, and through that operation awareness of the manifold content of experience constituted by the respective objects of the faculties' action. In a word, self-awareness comes built into a complex and constantly changing whole of experience. ${ }^{39}$

But to return to the worries over identity, do we not often perceive one content of experience leading to another in a manner that suggests the subject of experience remaining the same between them? For instance, it can only be my perception of an injustice that can cause anger in me. Indeed, Sadrā repeatedly relies on the Avicennian argument from the unity of experience which relies on such cases. ${ }^{40}$ Moreover, the very passage which stated the multiplicity of phases of the self shows Sadrā attributing the phases to a single self. Instead of settling with sheer incoherence, I believe we should conceive of the underlying unity of the self in the light of Șadrā's statement of the primacy of existence. Unlike Avicenna, who took the self to be a substance that is really separable from its corporeal cognition, emotion, and action, and who thereby grounded the unity of experience in an unchanging substantial core, Sadrā holds that the human self is one in the sense that her existence, conceived as a continuity, is one process of development. ${ }^{41}$ The diachronic identity of the self is no longer based on an essential core enduring the variations of its accidental attributes, but rather on the connectedness of the phases of change; or to be more precise, no question of diachronic identity or connection between discrete phases even arises on the primary level of existence, because the continuity is absolute, breakable only in analysis, not in itself. In this sense, it is

Paradigms and Western Transformations', Topoi 19 (2000), 59-61; and J. McGinnis, Avicenna (New York, 2010), 111-116.

${ }^{39}$ For other passages towards the same conclusion, see Asfār III.1.3.1, VI.151; III.1.3.1, VI.154-155; IV.8.7, IX.90.

${ }^{40}$ See n. 9 above.

${ }^{41}$ Asfār I.7.24, III.95; cf. IV.11.1, IX.265. 
illustrative to compare our existence to that of a piece of music in which individual notes and their combinations into harmonic and melodic composites owe their meaning to the piece as a whole. Notes and note combinations can of course be analyzed into isolated units of chords, motives, phrases, and so forth, but it would be foolish to identify the results of such analysis with the piece itself, or even to claim that they, when considered in isolation, are particularly informative of the whole. At the same time, the whole can be heard as a piece only by traversing through each and every phase, as a result of which the whole can never be perceived in the same manner as the phases - unless the piece is very short or one's shortterm memory capable of a rather unusual degree of retention. By the same token, we are never aware of ourselves as the whole of our existence, which seems to introduce a certain aspect of opacity to the very core of our being.

One can of course conceive the piece of music as a whole by identifying it with its score, which determines once and for all the meaning of each note and note combination. Analogous to the score, the temporal unfolding of our existence has an essential principle which directs our development and envelops it in a single continuity; in Sadrā's words, the self's "multiplicity is caused by unity, because it is the origin of multiplicity, its principle, model and goal". ${ }^{42}$ But just as the score can never be heard in its atemporality, the one unifying principle of our existence can only exist as a temporal continuity. Yet, unlike the score, the principle of our existence is internal to the development, indeed subject to it, in both senses of the term. As Șadrā stated in his explication of the Pythagorean anecdote, the self that is under development throughout its existence is completely present to itself at each phase. This is possible because at each phase of its existence the self is directed towards the goal of its development, which it carries in itself as a potency. At each phase of its existence, the self can only increase in the perfection of its existence by leaving the phase in which it

\footnotetext{
${ }^{42}$ Asfār IV.3.8, VIII.151; cf. Mafātīh XVII.5, 938-939.
} 
found itself and reaching a higher degree of existence. I can fully know what I am to become only by becoming and being it. ${ }^{43}$

This leads us to the question of how Sadrā can maintain both that the self is one and that our present self is distinct from our past and future selves. Fully in line with his general doctrine of the primacy of existence, he distinguishes between two levels of self-awareness: the primary level of absolute continuity of existence that develops towards increasing levels of perfection, and a secondary level on which the differences in perfection between the temporal phases of the primary level are grasped as distinct beings. On the primary level, "each of us knows intuitively, before resorting to demonstration, that his self (dhätahu) and reality is one thing, not many things." ${ }^{44}$ But just as existence is easily confused with its concept in metaphysical analysis, it is all too common to miss the primordial unity of the self's existence in a second-order reflective attention to oneself: "although this is something intuitive, most people cannot know it with respect to the art of knowledge, but deny this unity when they embark on inquiry and scrutiny $[\ldots] . "{ }^{, 45}$ Primitive self-awareness can only be had by simply and unreflectively being what you are. An act of second-order attention will distance its subject from that primitive level of being, and thereby introduce distinctions to what was both diachronically continuous and synchronically one to begin with. ${ }^{46}$ Although these distinctions are based on the degrees of perfection in the primitive unity of existence, the latter is not constituted by the discrete things that result from them.

Postulating these two levels of self-awareness allows Șadrā to make sense of how we can be unaware of our future selves, notwithstanding our full present disclosure to ourselves.

\footnotetext{
${ }^{43}$ Șadrā's argument against Fakhr al-Dīn al-Rāzī’s denial of the Avicennian doctrine, according to which God's essence is identical with His existence, is enlightening in this regard. Rāzî̀'s concern was that if we subscribe to this identification, we must accept the following scandalous inference: since we know what existence is, and since there is no difference between God's essence and pure existence, we (transitively) know God's essence. Șadrā's answer hinges on the relevant distinction: having a concept of a certain degree of perfection in existence is different from existing in that degree of perfection. (See Asfār I.1.10.2.1, III.488-489.)

${ }^{44}$ Asfār IV.8.5, IX.72-73.

${ }^{45}$ Asfār IV.8.5, IX.72-73.

${ }^{46}$ Cf. Asfär I.1.10.1.21, III.434-435. The point is made in passing also by Bonmariage, Le Réel et les réalités, 28-29, 43-45; and Kalin, Knowledge in Later Islamic Philosophy, 144-148.
} 
However, we do not yet have a satisfactory solution to the problem at the heart of the idea of the soul as a closed book. This is because the contents hidden within were supposed to consist, not of the increasing degrees of perfection to come, but of the future and present consequences of our past. ${ }^{47}$ In what sense can we be both fully aware of yet blind to this presently actual aspect of ourselves?

According to Șadrā, the diachronic continuity between the past and present phases of primitively self-aware existence is based on the fact that the later phase encompasses or includes the earlier, an idea which he epitomizes in a neat metaphor of human development:

indeed, the traveler towards God - I mean the soul - travels in itself ( $f \bar{\imath} d h \bar{a} t i h i)$, and passes through residences and stations that occur in himself through himself ( $f \bar{i}$ dhātihā bi dhätihā). So at every step it lays its foot upon its head, or rather its head upon its foot, and this is something astonishing; yet it is not astonishing upon verification and knowledge ( 'inda al-taḥq̄qi wa al- 'irfān). ${ }^{48}$

The self's earlier phases provide the basis for later development: one can develop only by surpassing what one presently is, that is, by using one's head as a step on the way upwards. But the later phase is higher because it is superior to the earlier, and since the properly human development consists in an increase in knowledge, an ascent from the lower modes of perception and imagination towards the summit of intellection, superiority in it must be in terms of knowledge. As the metaphor has it, in order to progress erect like a human being should, one must raise one's head, the corporeal seat of cognition in the Avicennian paradigm, to its proper place at the top of the human constitution.

\footnotetext{
${ }^{47} \mathrm{Cf}$. the above passage from the Shawāhid and the related text from the Mafātīh (see n. 33).

${ }^{48}$ Asfār IV.11.19, IX.403.
} 
At the same time, Sadrā insists that the ascent takes place in oneself, and that the later stages therefore amount to a superior cognitive perspective to the self. In an Aufhebungsprozeß of sorts, the later self (a properly seated head) is aware of itself as embedded in a process in which the present is inseparable from the past. Like the head requires the body for its subsistence, one can only know better by having undergone and incorporated the arduous process of learning. ${ }^{49}$ In this sense, I can legitimately identify with the I ten days, ten months or even ten years ago, all the interim changes notwithstanding; I would not be what I presently am were it not for all those humble moments of personal history. But evidently we are not explicitly aware of all that brought us here - mercifully enough. Although I can have a recollection of myself a decade into the past, I may equally well have all but forgotten what I was involved with ten minutes ago. By the same token, there are many things I now know, such as my wife's favorite brand of licorice, which I must have learned in the past, yet I have no recollection of ever having learned them. For all I know, such pieces of knowledge could be a priori for my present self, were it not for the implausibility of the very broad innatism this would entail.

Despite these imminent problems, Sadrā consistently discusses the related phenomena in terms of habituation which, as a consequence of his theses of cognitive unity and substantial development, he insists does not concern merely one's accidents but one's very self. In an extended argument against transmigration, Sadrā addresses the question of how human beings, their specific identity notwithstanding, can have as drastically different forms in the afterlife as the revealed sources suggest, and be re-embodied as apes, pigs, angels, devils and so forth. ${ }^{50}$ His answer is that the psychic counterparts of repeated acts and events,

\footnotetext{
49 Șadrā makes the point frequently, cf., for example, Asfār IV.4.5, VIII.208-209; IV.4.12, VIII.239-240; IV.10.1, IX.167-168. He also describes our development in moral terms (Asfār IV.8.3, IX.41), by comparing it to the various methods of acquiring knowledge (Asfār IV.10.4, IX.184-186; IV.11.9, IX.315-316), and in terms of an increase in activity (Asfär IV.11.24, IX.445).

${ }^{50} \mathrm{Cf}$. the extended discussion in Asfār IV.8.2; 12-32. Sadrā can interpret this material literally because he holds our imagination to remain capable of providing us with experienced bodies every bit as real as those we're now
} 
such as volitions and perceptions, are sedimented into individual character traits, and when these grow deeply rooted, they become one with the individual in a way that transcends the acts which generated them. However, as character traits they do not necessarily appear as explicit objects of awareness; rather, because of them the soul will be "informed by other forms", such as the various embodiments in the afterlife. Closer to home, we could say that the character traits appear embedded in the ways in which the whole of our experience is determined. ${ }^{51}$ In Șadrā's example, a perceived or narrated act of sexual intercourse will appear drastically different to an adult well-versed in the pleasures of the flesh than to an infant or someone otherwise incapable of or inexperienced in similar acts. ${ }^{52}$ Entirely in line with Șadrā's broad concept of cognitive unity, this is because of differences in the makeup of their respective selves, the characteristics of which enter into the determination of the entire act of mental existence concerned.

Șadrā also compares the self's obliquely apparent character traits to the shadows which our bodies cast as their often unregarded concomitants. ${ }^{53}$ But the concept is brought home particularly in his interpretation of the Qur'ānic motive of the opening of the soul's book.

We also say that the intoxication of nature and the stupor of the soul in this abode - due to its preoccupation with the deeds of the body - prevent it from apprehending the harms of the soul and the pains occurring to it, which are acquired from among the results of its deeds and the concomitants of its destructive character traits and habits (lawāzimi akhlāqihā wa malakātihā), by a true apprehension which is not spoiled by what the senses convey to it, what they are engaged in, forgetting and ignoring. Thus, when the veil is lifted from the human being by death and the cover is removed, on that day his sight falls upon the consequences of his acts and the

endowed with. The only difference is that in the afterlife nothing prevents our bodies from being non-human, for a human soul is necessarily related to a human body only when the extramental material body is concerned.

${ }^{51}$ Asfār IV.8.2, IX.29-30; cf. IV.10.4, IX.184; IV.11.20, IX.404-405, 407-408; and IV.11.26, IX.464.

${ }^{52}$ Asfār IV.10.3, IX.182. The same example is used by Avicenna in Ishārāt, 193.

${ }^{53}$ Cf. Asfār IV.8.2, IX.28; and IV.8.3, IX.45. 
results of his deeds, so that then - if he is mean in character traits, evil in deeds and destructive in beliefs - they end up in strong pain and great disaster. ${ }^{54}$

Immersed in the constant fluctuation of its mundanely engaged experience, the human soul is incapable of truly perceiving the consequences of its habituation. It is only aware of the traces of its character, and will lack a veridical perception of this opaque aspect of itself for as long as its interest-laden relation to the body prevails. With the exception of a few virtuosi of ascesis, for the common man only the cessation of the relation to the body in death liberates his awareness to turn immediately "upon the face of his self $[\ldots]$, the page of his interiority and the tablet of his conscience", down to the murkiest recesses of his being. ${ }^{55}$

That this opacity in us is a consequence of the Sadrian doctrines described above is shown by a later passage from the same context:

[E]very human soul, together with what houris, castles, trees and rivers are attached to it [in the afterlife], the whole of them exists through one existence and lives through one life, the whole with its individual unity of manifold forms.

When the human being departs from the world, divests of the garb of this nethermost, and this cover is removed from his sight, his apprehensive faculty is a power, his knowledge hidden, and what is hidden of him is manifest; so that he comes to see the consequences of his deeds and thoughts, to behold the traces of his movements and acts, reading the scroll of his deeds and the tablet of his book, his good and bad deeds. ${ }^{56}$

The identification of the individual soul with its particular share of the Garden is of course based on the idea of cognitive unity, and the content of that unity is in turn determined by the entire continuity of individual existence that has led to it. This is where the doctrine of the primacy of existence comes in, because the soul in Paradise can be this particular "individual

\footnotetext{
${ }^{54}$ Asfār IV.8.3, IX.48-49.

${ }^{55}$ Asfār IV.11.20, IX.408.

${ }^{56}$ Asfār IV.11.20, IX.411; cf. IV.11.21, IX.413-414; IV.11.26, IX.469.
} 
unity of manifold forms", describable in terms denoting an essence with attributes, only because on the foundational level it is a phase in a single continuous act of existence that gives the afterlife its content and meaning. And finally, the accumulation of determinations that account for the content of each soul's particular hereafter refers back to substantial motion. Indeed, the Qur'ānic motive of the final revelation about the self translates without residue to systematic philosophical terms:

Know $[\ldots]$ that the garden, to which he who is of its people will arrive, is visible to you today in respect of its substrate, not in respect of its form, and you dwell in it in the state you are in, yet you do not know that you are in it. ${ }^{57}$

The present state of the soul is a substrate for future development in the sense that it bears the potential for the increase in perfection. This it does by providing the content which the soul, informed by the superior regard of the later stage, will eventually identify with, realizing that what it held to be features of the world were in fact constitutive of itself. Rephrasing the point in terms of the aforementioned distinction between the two levels of self-awareness, we can say that the soul's initial opacity is due to the ways in which it analyzes the first-order unity of self-aware experience into the two seemingly independent constituents of itself as subject and the world as object. Although the analysis need not be entirely unwarranted by features inherent to the first-order unity, once its results are taken to be discrete entities the stage is set for confusion and neglect. For instance, I may be all too keen to perceive a salary increase as worthy in and of itself, but this is only because I fail to realize that the worth is ultimately based on the unity of this particular object (the salary increase) existing for this particular subject (me). If in a more elated moment I regard myself to be above such mundanities, I will only have become more opaque to myself, for my

\footnotetext{
${ }^{57}$ Asfär IV.11.26, IX.468; emphasis added.
} 
second-order consideration still hinges on an unwarranted distinction between the way the prospect appears and the me to which it appears as it does but which is capable of resisting its allure. On the first-order level of existence, the perceived worth of the salary increase is rooted in my self and can be eradicated only through my thorough transformation, by not only rising above the initial perception but also recognizing that and why I used to perceive it as I did.

Neither the idea of constant self-awareness nor that of acquired determinations of character traits are particular to Șadrā, but the way in which he combines the two ideas is quite unique. Instead of downplaying the tension by conceiving the frequently opaque character traits as mere accidents to the self that remains constantly transparent to itself, he heightens the perceived incompatibility of the two ideas by insisting on the inseparability of the self and its various determinations. This tension, as deep as its roots lie in a premodern soil, is not entirely unlike our postmodern wrestling with the inaccessibility of our ulterior motives or the social, economic and libidinal constitution of our selves. Shorn of the hermeneutic agenda and decidedly secular orientation of the Ricoeurian masters of suspicion, Sadrā's concept of the human self comes tantalizingly close to theirs: for him, too, there is a greater self beyond whatever I take to be myself, as close an acquaintance as possible with which should be the ultimate goal of all my moral striving. 